\title{
Impact of personality on the trust factor in E-wom communities
}

\author{
Mumtaz Reina Mendonça ${ }^{1}$
}

\author{
${ }^{1}$ Asst. Professor,Department of Commerce, \\ St. Xavier's College, Mapusa, Bardez-Goa. 403507
}

\begin{abstract}
The trust factor has been a centre of research on virtual communities, e-commerce and other web based environments. When it comes to virtual communities, distrust is latent if not clearly manifested. The availability and accessibility of consumer generated information in the form of product reviews posted on retailer and social media sites makes the shift easy thus centering on trust as the locus for the progress of virtual communities. Research has proven that a persons personality determines his behaviour in any environment and his subsequent propensity to trust. As a consequence, one's personality plays a significant role in affecting consumers' online shopping performance and attitude and Online Word of Mouth (consumer generated information) thus leading to posting and reviewing opinions online. This study aimed to suggest that as trust is a key element in fostering the voluntary online cooperation between strangers, it is one's personality that plays a significant role in influencing the level of trust displayed in online collaborative behavior (Electronic Word of Mouth, EWOM )among online shoppers. A model was developed that proposes that personality type as defined by the circumplex, affect the individual's trust and thereby affects willingness to collaborate and the sustainability and productivity of the online collaboration. The institutional and interpersonal trust constructs positioned trust as the mediating factor determining Personality type and corresponding collaborative behavior online. It proposes to understand trust dynamics at the dyadic and group levels.
\end{abstract}

Keywords: Personality, Electronic Worn Of Mouth, trust,

\section{Introduction:}

The Internet as a marketing channel, differs from the traditional retail forms in many ways. What is unique here is that consumers can not touch or smell the products that they wish to purchase as they would normally do in the case of traditional outlet forms.
They will have to base their judgments partly on the product information provided by the online portal about the respective product which may serve as the only reference and they will have to use their own instinct and insight into making a favourable purchase online. As a result, distrust and uncertainty in the mind of the consumers is the excrescence or fallout of online commerce. The important feature of online environment of the availability of consumer generated information in the form of product reviews posted on retailer and social media sites (Girish N. Punj, 2013) is the result of consumers searching for ways to overcome the trust factor. Trust is a key element in fostering the voluntary online cooperation between strangers seen in virtual communities (Catherine M. Ridings et al 2002 ). The members of virtual communities are typically strangers to one another and the nature of online interaction, without the cues that face-to-face contact affords, may require trust for successful communication, or, on the other hand, may inhibit the development of trust. (Catherine M. Ridings et al 2002). The particular personality characteristics that can potentially explain the propensity to trust are measures of the Big Five traits (Markus Freitag et al 2016). Given that trust could be essential in the information exchange of virtual communities, as it is in other communications (John K. Butler et al, 1994) . Trust is a significant predictor of virtual community member's desire to exchange information, and especially to get information (Catherine M. Ridings et al 2002).

As a consequence, one's personality plays a significant role in affecting consumers' online shopping performance and attitude and Online WOM (consumer generated information) thus leading to posting and reviewing opinions online. Circumplex theorists contend that the traits defined in the interpersonal circumplex influence trust as well as other cognitive and affective processes that may affect collaborative behaviour(Houghton G. Brown et al, 2004). This study contends to suggest that as trust is a key element in fostering the 
voluntary online cooperation between strangers, it is one's personality that plays a significant role in affecting the level of trust displayed in online collaborative behavior among online shoppers. Therefore in this study we develop propositions that trust is a mediating factor in the willingness of various personality types to the use and participation in EWOM.

Commercialization of the internet brought emergence of a new medium of commerce known as electronic commerce (Joshi, 2013; Vivek S. Tomar et al , 2018). The e-commerce share of total global retail, which was a mere $3.5 \%$ a decade ago, has currently reached to $11.9 \%$ and is projected to reach $17.5 \%$ by 2021(Lui, 2018). Though the largest markets for online sales are China and USA, but with the highest projected growth rate, India is the fastest growing market for online shopping (Nair 2017). In India, not only metros and large cities, even tier II and III cities and towns are registering considerable sales of products and services using online channel (Joshi et al, 2016). Forrester data on online retail forecast 2016-21(Asia Pacific) states that World over, apparel is the largest category for online retail of $\$ 167$ in net worth in billions with 9\% growth rate, followed by consumer electronics and computer hardware of $\$ 146$ in net worth in billions with $11.9 \%$ growth rate. However, grocery, beauty and cosmetics, home appliances and furniture are the fastestgrowing categories, showing the increasing maturity of online shopping in Asia Pacific. (Nair 2017). The beauty and cosmetics category has a net worth in billions of 39.2 coupled with a growth rate of $18.3 \%$.

\section{Literature review/theoretical framework and hypothesis development:}

\section{EWOM- Electronic Word of Mouth}

Economic and marketing studies have long shown that word-of-mouth (WOM) plays an important role in shaping consumer attitudes and behaviours (Xianghua Lu et al, 2013, Buttle 1998). The public has become increasingly reliant on online WOM information to make various decisions, ranging from what movie to watch (Dellarocas et al. 2007) to what shares to invest in or which books to read (Chevalier and Mayzlin 2006). This trend of online wom reliance has percolated even to high involvement products and services such as holiday destinations, electronic gadgets, clothing, fashion accessories, medical services etc.

[1] Lack of trust among consumers have led to doubt in the minds of the consumers and thus resulted in consumers leaving/ abandoning their cart without completing the online purchase. Online retailers have been constantly checking on consumers abandoned carts and devising ways to encourage consumers to go ahead with the purchase. E-marketers are constantly pursuing promotional tactics which intend to convert web viewers to customers such as product reviews by fellow consumers, style guide, wardrobe creation etc. Online retailers proactively encourage their consumers to spread the word about their products online or on the mobile app (Godes. D et al 2004). Online retailers have attempted to provide a proxy for advice from friends and salespeople through the use of e-commerce-based word-of-mouth (WOM) systems in order to build brand loyalty and trust ( Mc Williams G, 2000, Neveen F. Awad et al 2008). Several online WOM studies have suggested that companies should actively try to create WOM communications (Chen and Xie 2008, Godes and Mayzlin 2004, Liu 2006, Xianghua Lu et al 2013. Literature indicates four different motives for consumers to seek online product reviews: Information seeking, Risk reduction, Quality seeking and Social belonging (Bickart and Schindler, 2001; Burton and Khammash, 2010; Henning-Thurau et al 2004)

2. Trust: is seen as an essential prerequisite for cooperation, with numerous studies showing that a high level of social trust promotes an inclusive and open society, stimulates economic development, promotes democratic stability, and fosters societal happiness and a general feeling of well-being ( Delhey et al. 2011; Ermisch et al. 2009; Kramer 1999; Stolle 2002). A number of scholars marshal evidence that trust promotes cooperative behavior, a critical component of collaboration (Mayer, R.C et al 1995; McAllister 1995, Houghton G. Brown et al 2004). Trust increases peoples's desire to take risks for productive social exchange (Tyler 2001). Jones and George 1998 discuss seven distinct processes that trust promotes that may increase interpersonal cooperation and teamwork: broad, flexible role definitions, a communal rather than individualist orientation, high levels of confidence in others, helpseeking behavior, free exchange of knowledge and information, subjugation of personal needs and ego, and high levels of involvement in the activities of others. These processes mark trust as an important factor in collaboration. In virtual interaction, trust is likely to be particularly important, because collaboration can be effective only if both parties enter into it with a willingness to open themselves to one another and cooperate in carrying out a task, solving a problem, and learning (Jarvenpaa, J.S et al 1998). Pavlou provides evidence that trust in an ecommerce site directly affects the consumers' intention to transact and also affects perceived risk, perceived usefulness, and perceived ease of use, which in turn also affect intention to transact (Pavlou 2003). Pavlou focuses on the user's current state of 
trust; we intend extend his model to propose that personality traits as spelt out in the NEO-FFI and consequential disposition to trust influence one's technology acceptance and subsequent participation in EWOM. As McKnight et al 1998 argue, when an individual is unfamiliar with another person or setting (McKnight et al 2001), it is not the individual's trust that precipitates his willingness to engage or accept the technology, but rather, it is his disposition to trust. This disposition, we will argue, is a function of one's personality traits, and one's traits, in turn, impact the quality and effectiveness of a technology- enabled participation and collaboration. In addition, we will argue that some personality types are more open to innovation and learning new technologies than others. Mondak and Halperin(2008) find only a relationship between the trait of agreeableness and generalized trust, but not for other traits (see also Anderson 2010; Dohmen et al. 2008). By contrast, Dinesen et al.(2014) show that all personality traits affect generalized trust. Hiraishi et al (2008), again, find that agreeableness as well as extraversion is related to generalized trust. Oskarsson et al.(2012) establish that generalized trust is related to extraversion, personal control, and intelligence.

\section{Social Trust In Virtual Communities:}

Some typical features of virtual communities may hinder trust development, such as the lack of face-toface contact and visual cues. In addition, the identities of fellow community members may be a cause of doubt and suspicion since it is easy to mask one's gender, age, etc. online. On the other hand, the closeness in the community developed because of the strong mutual interest in the community's topic, especially in the cases of health concerns or life events such as the birth of a baby or death of a parent, may foster the development of trust (Catherine M. Ridings et al 2002). The continuous interaction with others and the open public reply and debate of messages may also help trust evolve (Catherine M. Ridings et al 2002).

4. Personality Traits: The Big Five personality traits are drawn as the characteristics that may potentially explain the propensity to trust. Consumer researchers have been intrigued by the concept of personality and its relationship to consumer behaviour in part because key personality factors are believed to have persistent influence on perception and behaviour (Erikson, 1968; Haugtvedt, Petty and Cacioppo, 1992, Mendonca 2016). By rule, a personality should provide a rather consistent response to an environmental stimuli based on enduring psychological characteristics (Kassarjian 1971). But as per a review of over 300 personality studies, the impact of personality on consumer behaviour was described as ambiguous at best (Kassarjian and Sheffet, 1991). According to Moore, Harris, and Chen, 1995, Mumtaz 2016; traits have been found to be especially useful in consumer research when they have direct relevance to the specific buying behaviour being investigated. A trait is a characteristic or individual difference in which one person varies from another in a relatively permanent and consistent way (Mowen and Minor 1998). Traits theory is important in studying consumer behaviour because traits are common to many individuals (Engel, Blackwell and Miniard.1995). Scholars have shown that personality traits have motivational implications, play a role in influencing the characteristics a person perceives as relevant in her environment, the goals a person pursues, and how she responds to external stimuli (e.g., Costa and McCrae 1988). Thus for this study purpose, attention is placed on how personality traits affects the trust factor among online shoppers towards their involvement in EWOM. The study uses the Big Five personality inventory to examine its influence on trust and consequently on consumer behavior towards EWOM.

Personality psychology has recognised five broad traits (the Big Five) that explain much of the meaningful variance in the innumerable traits proposed in the earlier literature (Todd A. Mooradian et al 2008). Therefore, the most widely accepted taxonomy of personality traits is the Big Five or fivefactor model (John and Shrivastav 1999; McCrae and Costa 1999; Gosling S.D.et al 2003). The Big Five factors are Openness to Experience (also called Intellect or Culture), Conscientiousness, Extraversion, Agreeableness, and Neuroticism (also called Emotional Stability). These factors represent personality at the broadest level of abstraction. Each factor summarizes a large number of distinct, more specific, personality characteristics.

Reliability coefficients for the subscales have been established as acceptable (Extraversion, $\alpha=0.87$, Agreeableness $\alpha=0.82$, Conscientiousness $\alpha=0.79$, Neuroticism $\alpha=0.86, \quad$ Openness to Experience/Intellect $\alpha=0.84$ ) (Goldberg 1999).

\section{Personality Traits And Social Trust:}

(Markus Freitag et al 2016 ) has shown in their study that the impact of personality traits on trust in strangers is stronger than in friends. Personality, is a "multifaceted, enduring, internal psychological structure" (Mondak et al. 2010). Traits as the core component of personality cannot be observed directly, but are inferred from behavior (McCrae and Costa 2008). They appear to be rooted in genetic factors and are highly stable through the life cycle (Mondak et al 2010). The particular personality 
characteristics we consider as potentially explaining the propensity to trust are measures of the Big Five traits. This framework comprises five personality traits that emerge regardless of differences in cultures and languages, suggesting that they capture a human universal (Gallego and Oberski 2012). The traits are: openness to experience, agreeableness, conscientiousness, extraversion, and neuroticism. Importantly, the "Big Five" are indeed "big" concepts in that they encompass "hundreds, if not thousands, of traits" (Goldberg 1993) and are regarded as "broad domains, collectively representing a hierarchy that organizes and summarizes the vast majority of subsidiary traits" (Mondak 2010). Since its introduction, the Big Five framework "has become the most widely used and extensively researched model of personality" (Gosling et al 2003).

Agreeable individuals "are trusting, believing the best of others and rarely suspecting hidden intents"(McCrae and Costa 2003). Much more than any other trait, agreeableness describes how a person behaves in interactions with others (Mondak 2010). Agreeable persons are cooperative, warm, kind, and avoid conflicts. Persons with high agreeableness show a caring and kind orientation toward other people. They are interested in having good relationships with their fellow citizens and characterized by a communal orientation. In general, agreeableness should be accompanied by high levels of trust in other people, since agreeable persons simply tend to "believe the best of others" (McCrae and Costa 2003).

Hypothesis 1: Personality trait "Agreeableness" is positively associated with trust in ewom communities.

Extraversion "concerns differences in preference for social interaction and lively activity" (McCrae and Costa 2003). This trait comprises facets such as warmth, gregariousness, positive emotions, and assertiveness( Markus Freitag et al 2016). Extraversion applies to those who are more sociable, lively, and active, whereas its opposite, introversion, indicates a tendency toward withdrawal, passivity, and shyness (McCrae and Costa 2003). In contrast to introverts, we assume that extraverts display higher levels of trust, which go hand in hand with the desire for social interaction and communication. However, it is also assumed that high scorers on this trait are socially dominant and endorse hierarchy, which would lead people to be more cautious against others (Markus Freitag et al 2016). Tauber (1972) has argued that one of the prime motives for shopping is the desire to communicate with others who have similar interests, to share ideas about particular products with shopping companions, to seek their feedback and to enjoy leisure time with friends and family. Since the physical separation constraint may be alleviated by online shopping, thus making online shopping a medium to socialise and interact. Further, it is perceivable that social connectedness facilitates the spread of word of mouth, which has been found to have a strong influence on the adoption of innovation (M. Naseri and G. Elliott, 2011). Sultan et al (1990), indicated from their study that word of mouth is the main deriver of diffusion of new products. Gefen and Straub (2003) have found that social presence affects consumers trust, which in turn influences their purchase intentions. Because one of the main objectives of collaborative online shopping is to fulfill people's desire for social interaction (Schubert 2000, Tauber 1972), extraverted individuals will use the internet as a tool to acquire things to share with others, such as information and music (Amiel, Sargent 2004).

Hypothesis 2 Personality trait "Extraversion" is positively associated with trust in ewom communities.

Neuroticism as a dimension to personality measures feelings of distrust, inferiority, loneliness, fear and anxiety . Neuroticism describes "the proneness of the individual to experience unpleasant and disturbing emotions and to have corresponding disturbances in thoughts and actions"(McCrae and Costa 2003; Vestre 1984). Neurotic individuals are nervous, high-strung, tense, and, as a result, prone to worry and generally dwell on what might go wrong. This trait encompasses anxiety as a facet, and because the corresponding individuals have a tendency to worry more, they should display lower levels of trust. When such individuals judge the trustworthiness of others it is more likely that they envision negative scenarios. People who score high on neuroticism are more likely to perceive a potential betrayal by the trustee and, consequently, are less likely to trust them. Neuroticism is reflected in a negative reaction to both life and work situations, and this will generalize to beliefs about the perceived usefulness of technology (Sarv Devaraj et al 2008). The distrust inherent in people with neurotic personalities has tended to limit the amount of time they spend online exchanging information (Swickert et al 2002). Neurotic personalities are likely to view technological advances as threatening and stressful, and to have negative thought processes when considering it (Sarv Devaraj et al 2008). This negativity towards online shopping is aggravated since internet shopping inherently involves higher levels of uncertainty than shopping from a physical store because the activity is new to most people, and the transactions are conducted in a virtual environment without the physical assurances of 
traditional shopping experiences (Kai H. Lim et al 2004).

Hypothesis 3: People Personality trait "Neuroticism" is negatively associated with trust in ewom communities.

Openness to experience refers to a "receptiveness to new ideas, approaches, and experiences" (McCrae and Costa 2003 )and is represented by flexibility of thought and tolerance of new ideas (Mendonca 2016). This trait encompasses the tolerance of diversity, the broadness of a person's cultural interest, and exploration of novelty. Persons who score high on this dimension are curious, imaginative, and original, while persons who exhibit low scores tend to be cautious and conservative (McCrae and Costa 2003). Moreover, this trait has been linked to risk taking (Kowert and Hermann 1997). Generally, it is argued that people who score high on this trait can be expected to have a high level of trust due to their tolerant and open-minded nature (Dinesen et al. 2014) and are willing to try new and different things (Sarv Devaraj et al 2008). Accordingly, we assume that the positive effect of openness on social trust.

Online shopping becomes an interesting field as it provides unlimited supply, unrestricted opening hours and supports the consumer by endless choices of price and product comparisons. Donthu and A. Gracia (1999) found that internet shoppers are more convenience seekers, innovative, variety-seekers. Open people are attracted to online activity to satiate their curiosity and seek out new forms of adventure (Tuten, Bosnjak 2001).

Hypothesis 4: Personality trait "Openness to experience" is positively associated with trust in ewom communities.

Consciousness likened with qualities of order, persistence, dutifulness, purposeful and motivation in goal directed behavior (Mendonca 2016) and are considered as rational, informed, and generally think of themselves as being high in competence (McCrae and Costa 2003). Persons at the high end of this scale are thorough, organized, ambitious, make plans in advance, and think before acting; whereas their counterparts at the lower end are immature, impatient, lazy, careless, and volatile (McCrae and Costa 2003). All in all, individuals scoring high on this trait seem to be more cautious and seek to be better informed (Mondak 2010). Moreover, conscientious individuals value control (Dinesen et al. 2014).

Conscientious people are less likely to use the internet for what they see as unproductive activities. They also tend to spend less time online in leisure pursuits (e.g. watching YouTube videos (Landers,
Lounsbury, 2006).. Conscientious individuals are inclined to carefully process and weight additional information (Sarv Devaraj et al 2008). Therefore, it is safe to assume that higher levels of conscientiousness should correspond to lower levels of trust.

Hypothesis 5: Personality trait "Conscientiousness" is negatively associated with trust in ewom communities.

\section{RESEARCH MODEL}

Trust is positioned as a mediating variable. Given that trust could be essential in the information exchange of virtual communities, as it is in other communications (K.Butler and Cantrell, 1994), it is desirable to realise what builds trust and how trust, in turn, is related to the outcome variables of giving and getting information. First, the antecedents of trust are presented and each is, in turn, linked to trust.

McKinght et al 2001 conducted an extensive research of approximate 65 books and journals on the definitions of trust The articles and books were from the fields of psychology/ social psychology (23), sociology/economics/political science (19), and either management or communications (23). An analysis of these definitions showed that they fell into two broad groupings. Many of them could be categorized into different conceptual types, such as attitudes, beliefs, behaviors, and dispositions, whereas others could be categorized as reflecting different referents: trust in something, trust in some one, or trust in a specific characteristic of someone (e.g., honesty).

The institutional and interpersonal trust constructs are discriminant from each other for at least three reasons. First, they come from different research disciplines.

Institution-based trust derives from sociology, which says that behaviors are situationally constructed. In this paradigm, action is not determined by factors within the person but by the environment or situation.

Trusting beliefs and intentions (benevolence) reflect the idea that interactions between people and cognitive-emotional reactions to such interactions determine behavior (McKinght et al 2001).

\section{MEASURES:}

To construct the survey instrument, existing scales from the literature were reviewed and items were 
ISSN 2455-6378

carefully adapted or developed for each construct. Then a pretest was conducted in which four individuals who frequent virtual communities reviewed the survey. Minor revisions were made to the survey as a result of the pretest.

Figure 1: Impact of personality on the trust factor in E-WOM communities.

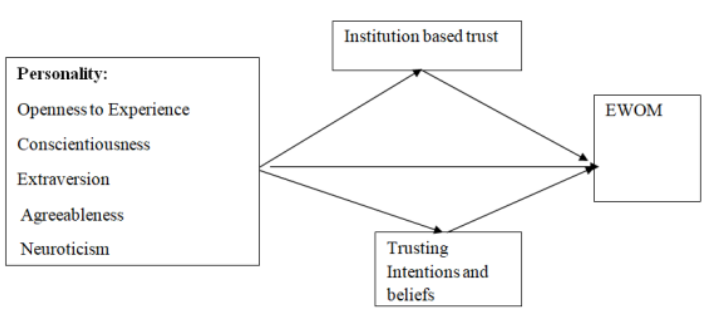

Figure 1. A Proposed Model for Impact of Personality on Trust factor in EWOM Communities.

\section{Materials and methods:}

1. Measurement Scale:

An instrument was designed consisting of 31 items, to measure the participants perception and behaviour towards EWOM measuring the two constructs of trust in an online environment. All of the items were measured with five point Likert-type scales ranging from strongly disagree to strongly agree.

Institution based trust: No existing scale could be found to measure the degree to which people trust and confide in institutions (online) as a community. Thus, a scale was developed specifically for this study. The scale was pretested.

Trusting beliefs and intentions (benevolence): the scale was adapted from Catherine M. Ridings 2002.

EWOM: a scale was developed specifically for the study and pretested.

This study used a convenience sample of 63 respondents, who were asked to complete the questionnaire, demographics information such as age, gender, were a part of the study. The sample consisted of 40 females and 23 males. The period of the study is seven months starting from February to August 2019.

\section{Analysis and Results:}

1.Descriptive Statistics: The demographic characteristics of the respondents are depicted in Table 1.
Table 1: Basic Profile of Respondents

\begin{tabular}{|l|l|l|}
\hline Characteristics & Category & Percent (63) \\
\hline Gender & Male & 50.8 \\
\cline { 2 - 3 } & Female & 49.2 \\
\hline \multirow{4}{*}{ Age } & Below 20 & 17.5 \\
\cline { 2 - 3 } & $21-30$ & 61.9 \\
\cline { 2 - 3 } & $31-40$ & 17.5 \\
\hline & $41-50$ & 1.6 \\
\hline & Above 50 & 1.6 \\
\hline
\end{tabular}

Source: Primary data

2. Measurement Model: The reliability and validity of the scales were evaluated before testing the hypothesis. The instrument consisting of 31 items, measuring the constructs was determined by Principal Component of factor Analysis with Varimax rotation to verify that pertinent indicator variables were selected for each of the constructs. To set the criteria for principal component analysis, factors with eigenvalues greater that 1.0 and items with rotated factor loadings of 0.50 or greater were retained. The KaiserMeyer-Olkin measure of sampling adequacy was 0.6 which is the minimum requirement for a good factor analysis. As, communality of a variable represents the amount of variance in the factor solution explained by that variable (Hair 1998), variables with communalities less than 0.40 were eliminated for reasons of insufficient contribution to explain the variance. Variables that did not meet the above criteria were excluded for the analysis. Among the 31 items, 13 items were retained (Table 2 ). 
Table 2: Outer Loadings of Constructs

\begin{tabular}{|l|c|c|c|}
\hline & $\begin{array}{c}\text { Institution } \\
\text { based Trust }\end{array}$ & Benevolence & EWOM \\
\hline $\begin{array}{l}\text { The other consumers/users have much knowledge about the subject we } \\
\text { discuss. }\end{array}$ & 0.682 & & \\
\hline $\begin{array}{l}\text { I feel very confident about the skills that the other consumers/users have } \\
\text { in relation to the topics we discuss. }\end{array}$ & 0.666 & & \\
\hline $\begin{array}{l}\text { The other consumers/users have specialized capabilities that can add to } \\
\text { the conversation online }\end{array}$ & 0.605 & 0.57 & \\
\hline $\begin{array}{l}\text { The other consumers/users are very capable of performing tasks in the } \\
\text { topics we discuss }\end{array}$ & 0.564 & & \\
\hline $\begin{array}{l}\text { The other consumers/users seem to be successful in the activities they } \\
\text { undertake }\end{array}$ & & & \\
\hline I feel that people are generally reliable while interacting online & & 0.511 & \\
\hline I can always count on getting a lot of responses to my posts. & & 0.835 & \\
\hline The consumers/users are very responsive to my posts & & 0.583 & \\
\hline I can always count on getting responses to my posts fairly quickly & & 0.551 & \\
\hline $\begin{array}{l}\text { In my opinion, the consumers/users do not behave in a consistent manner } \\
\text { online. }\end{array}$ & & & 0.837 \\
\hline I search online as and when I want advice on how to carry out some task & & & 0.706 \\
\hline I consult online when I need facts about a particular subject & & \\
\hline I search online reviews to get information on a particular topic & & \\
\hline
\end{tabular}

Table 3:Key measures in the Instrument:

\begin{tabular}{|c|c|c|c|}
\hline Construct & Mean & $\begin{array}{c}\text { Std. } \\
\text { deviation }\end{array}$ & $\begin{array}{c}\text { Cronbach } \\
\text { Alpha }\end{array}$ \\
\hline $\begin{array}{c}\text { Institution } \\
\text { based trust }\end{array}$ & 3.3 & 0.94 & 0.75 \\
\hline Benevolence & 3.2 & 1.03 & 0.78 \\
\hline EWOM & 4.14 & 0.82 & 0.82 \\
\hline
\end{tabular}

Collinearity (VIF) Statistics: The tolerance to VIF rule of less than .1 and vif (Variance Inflation factor) greater than 10 and .2 and 5 are guidelines for cutoff. So taking the correlation between openness and extraversion being high (.556) taking .6 as the cutoff, Extraversion (Hypothesis 2) was being excluded from the analysis as mentioned in Table 4.

Table 4: Collinearity Statistics

\begin{tabular}{|l|r|r|}
\hline \multirow{2}{*}{\multicolumn{1}{|c}{ Model }} & \multicolumn{2}{|c|}{ Collinearity Statistics } \\
\cline { 2 - 3 } & Tolerance & \multicolumn{1}{c|}{ VIF } \\
\hline (Constant) & 0.888 & 1.126 \\
\hline Neuroticism & 0.966 & 1.035 \\
\hline $\begin{array}{l}\text { Openness to } \\
\text { Experience }\end{array}$ & 0.97 & 1.031 \\
\hline Agreeableness & 0.915 & 1.093 \\
\hline Conscientiousness & & \\
\hline
\end{tabular}

\section{Results:}

1. The results for each of the three constructs are summarized in Table 3. Since a five point Likert scale was used to measure the intensity of each construct, a mean score of 2.5 indicates a neutral response, while a mean score of 1 represents an extremely negative response and a mean score of 5, an extremely positive response. Respondents exhibited a high level of response for all the three constructs.

2. The four hypothesis were tested using Hayes Process Macro Version 3.4 for mediation with Institution based trust and Benevolence (trusting intentions and beliefs) as mediators. Bootstrapped tests on the indirect effects of the mediators were performed.

Hypothesis 1: The Personality trait "Agreeableness" effect on EWOM is negative and is not statistically significant $(b=-0.0443$, s.e. $=0.18, p>0.05)$. The unstandardised indirect effect of Personality trait "Agreeableness" on EWOM via the first mediator (Institution based trust) is 0.0109 and is not statistically significant as 0 falls between -0.0308 and 0.1411 and the unstandardised indirect effect of Personality trait "Agreeableness" on EWOM via the second mediator (Trusting intentions and beliefs) is 0.0336 and is not statistically significant as 0 falls between -.0852 and 0.1323 .

Hypothesis 3: The Personality trait "Neuroticism" effect on EWOM is positive and is statistically significant $(b=0.36$, s.e. $=0.17, p<0.05$. The unstandardised indirect effect of Personality trait "Neuroticism" on EWOM via the first mediator (Institution based trust) is 0.025 and is not statistically significant as 0 falls between -0.057 and 
0.11 and the unstandardised indirect effect of Personality trait "Neuroticism" on EWOM via the second mediator (Trusting intentions and beliefs) is 0.01 and is not statistically significant as 0 falls between -.05 and 0.10 . The total effect of personality trait "Neuroticism" on EWOM is $(b=0.40$, s.e. $=0.17, \mathrm{p}<0.05)$.

Hypothesis 4: The Personality trait "Openness to experience" effect on EWOM is positive but not statistically significant $(b=0.04$, s.e. $=0.27, p>0.05)$. The unstandardised indirect effect of Personality trait "Openness to experience" on EWOM via the first mediator (Institution based trust) is -0.04 and is not statistically significant as 0 falls between -0.23 and 0.05 and the unstandardised indirect effect of Personality trait "Openness to experience" on EWOM via the second mediator (Trusting intentions and beliefs) is -0.038 and is not statistically significant as 0 falls between -.2811 and 0.0865

Hypothesis 5: The Personality trait Consciousness effect on EWOM is negative but not statistically significant $(b=$ 0.02 , s.e. $=0.17, \mathrm{p}>0.05$. The unstandardised indirect effect of Personality trait "Consciousness" on EWOM via the first mediator (Institution based trust) is 0.03 and is not statistically significant as 0 falls between -0.023 and 0.16 and the unstandardised indirect effect of Personality trait "Consciousness" on EWOM via the second mediator (Trusting intentions and beliefs) is -0.007 and is not statistically significant as 0 falls between -.0835 and 0.041

\section{LIMITATIONS AND SCOPE FOR FUTHER RESEARCH:}

The first limitation of the study is the use of a convenient sample rather than a random one, since this may have introduced a sampling bias. In order to have further confidence in the stability of these results, the study needs to be supported by a further analysis of a larger sample size. The building and maintenance of trust as a mediating factor to EWOM is an ongoing process with its own set of dynamics and thus many vary in consequences and antecedents and may incite controversy and further investigation. Besides personality, national culture may have an impact on trust (Jarvenpaa et al, 1999) which needs to be looked and investigated into.

\section{References:}

[1] Anderson, Mary R. (2010), Community psychology, political efficacy, and trust, Political Psychology, 31, 59-84 [in text citation: Anderson, 2010].

[2] Bickart, Barbara \& M. Schindler, Robert (2001), Internet Forums as Influential Sources of Consumer Information, Journal of Interactive Marketing 15(3) 31-40 [in text citation: Bickart and Schindler, 2001].

[3] Burton, Jamie \& Khammash, Marwan (2010), Why do people read reviews posted on consumer-opinion polls?, Journal of Marketing Management. 26(3), 230255 [in text citation: Burton and Khammash, 2010].

[4] Amiel, T., and Sargent, S. L. (2004), Individual Differences in Internet Usage Motives, Computers in Human Behavior, 20 (6), 711-726 [in text citation: Amiel, Sargent, 2004].
[5] Buttle FA (1998), Word of mouth: Understanding and managing referral marketing, Strategic Marketing, 6(3), 241-254 [in text citation: Buttle, 1998].

[6] Costa, Paul T, and Robert R. McCrae (1988), From catalog to classification: Murray's needs and the five factor model, Journal of Personality and Social Psychology, 55, 258-65 [in text citation: Costa and McCrae, 1988].

[7] Catherine M. Ridings, David Gefen, Bay Arinze (2002), Some antecedents and effects of trust in virtual communities, Journal of Strategic Information Systems ,11, 271-295.[ in text citation: Catherine M. Ridings et al, 2002]

[8] Chen Y, Xie J (2008), Online consumer review: Wordof-mouth as a new element of marketing communication mix, Management Sci. 54(3), 477491[ in text citation: Chen and Xie, 2008].

[9] Chevalier JA, Mayzlin D (2006), The effect of word of mouth on sales: Online book reviews. J. Marketing Res. 43(9), 345-354 [ in text citation: Chevalier and Mayzlin, 2006].

[10] Donthu, N. and Gracia, A. (1999), The internet shopper, Journal of Advertising Research, 39(3), 52-58 [in text citation: Donthu and A. Gracia, 1999].

[11] Dellarocas, Chrysanthos \& Zhang, Xiaoquan Michael \& F. Awad, Neveen(2007), Exploring the Value of Online Product Reviews in Forecasting Sales: The Case of Motion Pictures, Journal of Interactive Marketing. 21(4), 23- 45 [in text citation: Dellarocas et al, 2007]

[12] Delhey, Jan, Kenneth Newton, and Christian Welzel (2011), How General Is Trust in Most People? Solving the Radius of Trust Problem, American Sociological Review, 76, 786-807 [in text citation: Delhey et al, 2011].

[13] Dohmen, Thomas, Armin Falk, David Huffman, and Uwe Sunde (2008), Representative trust and reciprocity: prevalence and determinants, Economic Inquiry, 46, 84-90 [in text citation: Dohmen et al, 2008].

[14] Dinesen, Peter Thisted, AsbjørnSonneNørgaard, and Robert Klemmensen (2014), The Civic Personality: Personality and Democratic Citizenship, Political Studies, 62, 134-152 [in text citation: Dinesen et al, 2014].

[15] Engel, James F., Roger D. Blackwell and Paul W. Miniard (1995), Consumer Behaviour, Orlando, FL: The Dryden Press [in text citation: Engel, Blackwell and Miniard, 1995].

[16] Erikson, Erik H. (1968), Identity, New York, NY: Norton [in text citation: Erikson, 1968].

[17] Ermisch, John, Diego Gambetta, Heather Laurie, Thomas Siedler, and S. C. Noah Uhrig (2009), Measuring people's trust, Journal of the Royal Statistical Society, 172, 749-769 [in text citation: Ermisch et al, 2009].

[18] Gosling, Samuel D., Peter J. Rentfrow and William B. Swann Jr. (2003). A very brief measure of the Big Five Personality Domains, Journal of Research in Personality, 37,(6), 504-28 [ in text citation: Gosling S.D et al, 2003].

[19] Goldberg L. R. (1999), A broad bandwidth, public domain, personality inventory measuring the lower level facets of several five factor models, Personality 
Psychology in Europe,7, 7-28 [ in text citation: Goldberg 1999].

[20] Gefen, D., D. Straub (2003), Managing user trust in B2C e-services, e-Service J. 2(2) 7-24 [in text citation: Gefen and Straub, 2003].

[21] Gallego, Aina, and Daniel Oberski (2012), Personality and political participation: The mediation hypothesis, Political Behavior, 34, 425-451 [in text citation: Gallego and Oberski, 2012].

[22] Goldberg, Lewis R. (1993), The structure of phenotypic personality traits, American psychologist, 48, 26-26 [in text citation: Goldberg, 1993].

[23] Girish N. Punj (2013), Do consumers who conduct online research also post online reviews? A model of the relationship between online research and review posting behavior, Marketing Letters, 24(1), 97-108. [in text citation: Girish N. Punj, 2013]

[24] Godes D, Mayzlin D (2004), Using online conversations to study word-of-mouth communication, Marketing Sci. 23(4), 545-560 [in text citation: Godes. D et al, 2004].

[25] Hennig-Thurau, T., Gwinncr, K. P., Walsh, G., \& Gremler, D. D. (2004), Electronic word-of-mouth via consumer-opinion platforms: what motivates consumers to articulate themselves on the Internet?, Journal of Interactive Marketing,18( 1), 38-52 [in text citation: Henning-Thurau et al, 2004].

[26] Hiraishi, Kai, Shinji Yamagata, Chizuru Shikishima, and Juko Ando (2008), Maintenance of genetic variation in personality through control of mental mechanisms: A test of trust, extraversion, and agreeableness, Evolution and Human Behavior, 29, 7985 [in text citation: Hiraishi et al 2008]

[27] Haugtvedt, Curtis P., Richard E. Petty and John. T. Cacioppo (1992), Need for Cognition and advertising: understanding the role of personality variables in consumer behaviour, Journal of Consumer Psychology, 1, 239-260 [in text citation: Haugtvedt, Petty and Cacioppo, 1992].

[28] Hair Jr., J. F. (1998). Multivariate Data Analysis with Readings. Englewood Cliffs, NJ: Prentice-Hall [in text citation: Hair 1998].

[29] Houghton G. Brown, Marshall Scott Poole and Thomas L. Rodgers (2004), Interpersonal Traits, Complementarity, and Trust in Virtual Collaboration, Journal of Management Information Systems, 20 (4), 115-137. [ in text citation: Houghton G. Brown et al, 2004].

[30] Jones, G.R., and George, J.M. (1998), The experience and evolution trust: Implications for cooperation and teamwork. Academy of Management Review, 23 (3), 531-546 [in text citation: Jones and George, 1998].

[31] Joshi, D. J (2013), An analysis of the existing literature of B2c e-commerce, Indian journal of marketing, 43 (12), 34-46 [ in text citation: Joshi, 2013]

[32] John, O.P, and Srivastava, S (1999), The Big Five Trait taxonomy: History, measurement and theoretical perspectives, Handbook of Personality: Theory and Research, eds. Lawrence A. Pervin and Oliver P. John. New York: Guilford Press, 102-138 [in text citation: John and Shrivastav, 1999].

[33] Joshi D, Achuthan. S (2016), A study of trends in B2C online buying in India, Indian journal of marketing, 46 (2), 22-35 [ in text citation: Joshi et al, 2016]
[34] Jarvenpaa, J.S, Knoll, K and Leidner (1998), D.E. Is anybody out there? Antecedents of trust in global virtual teams, Journal of Management Information Systems, 14 (4), 29-64 [in text citation: Jarvenpaa, J.S et al 1998].

[35] Jarvenpaa, S.L., Tractinsky, N, Vitale (1999), Consumer trust in an internet store, Information Technology and Management, 1, 1/2 (1999), 45-72 [in text citation: Jarvenpaa et al, 1999].

[36] Kramer, Roderick M. (1999), Trust and Distrust in Organizations: Emerging Perspectives, Enduring Questions, Annual Review of Psychology, 50, 569598 [in text citation: Kramer, 1999].

[37] Kai H Lim, Kwok Leung, Choon Ling Sia and Matthew K.O. Lee (2004), Is ECommerce boundaryless? Effects of individualism-collectivism and uncertainty avoidance on Internet shopping, Journal of International Business Studies, 35, 545-559 [in text citation: Kai H. Lim et al, 2004].

[38] Kowert, Paul A., and Margaret G. Hermann. (1997), Who takes risks? Daring and caution in foreign policy making, Journal of Conflict Resolution, 41, 611-637 [in text citation: Kowert and Hermann, 1997].

[39] Kassarjian, H.H.(1971), Personality and Consumer Behaviour, Journal of Marketing Research, 8, 409-418 [in text citation: Kassarjian, 1971].

[40] Kassarjian, H. H and Mary Jane Sheffet (1991), "Personality and consumer behaviour: An update" in Perspectives in Consumer Behaviour, eds. $\mathrm{H}$. Kassarjian, and T. Robertson, Englewood Cliffs, NJ: Prentice-Hall, 281-303 [in text citation: Kassarjian and Sheffet, 1991].

[41] K. Butler, John \& Stephen Cantrell, R. (1994), Communication factors and trust: An exploratory study, Psychological Reports, 74(1), 33-34 [in text citation: Butler and Cantrell, 1994].

[42] Liu Y (2006), Word-of-mouth for movies: Its dynamics and impact on box office receipts, J. Marketing, 70(3) 74-89 [in text citation: Liu, 2006].

[43] Landers N. Richard, Lounsbury W. John (2006), An Investigation of Big five and narrow Personality Traits in relation to internet usage, Computers in Human Behaviour, 22(2), 283-293 [in text citation: Landers, Lounsbury, 2006].

[44] Lui, H (2018 April 24), What is the future of ecommerce in 2018 and beyond? 10 trends. ShopifyPlus. Retrieved from https:// www.shopify.com.enterprise/the-future-ofecommerce [in text citation: Lui, 2018].

[45] Markus Freitag and Paul. C. Bauer (2016), Personality Traits and the Propensity to Trust Friends and Strangers, The Social Science Journal, 53(4), 467-476 [ in text citation: Markus Freitag et al, 2016]

[46] Mc. Williams (2000), Building strong brands through online communities, MIT Sloan Management Review, 41( 3), 43-54 [in text citation: Mc Williams G, 2000].

[47] Mayer, R.C.; Davis, J.H.; and Schoorman, F.D (1995), An integrative model of organizational trust, Academy of Management Review, 20(3), 709-734 [in text citation: Mayer, R.C et al, 1995].

[48] McAllister, D.J. (1995), Affect- and cognition-based trust as foundations for interpersonal cooperation in organizations, Academy of Management Review, 38 (1), 24-59 [in text citation: McAllister, 1995]. 
[49] McKnight, D.H.; Cummings, L.L.; and Chervany, N.L (1998), Initial trust formation in new organizational relationships, Academy of Management Review, 23 (3), 473-490 [in text citation: McKnight et al, 1998].

[50] McKnight, D.H., and Chervany, N.L. (2001), What trust means in e-commerce customer relationships: An interdisciplinary conceptual typology, International Journal of Electronic Commerce, 6 (2), 35-59 [in text citation: (McKnight et al, 2001].

[51] McCrae, R.R., and Costa (2003), Personality in adulthood: A five-factor theory perspective" (2nd edition), New York, Guilford Press [in text citation: McCrae and Costa, 2003].

[52] Mohammad Bakher Naseri and Greg Elliott (2011), Role of demographics, social connectedness and prior internet experience in adoption of online shopping: Application for direct marketing, Journal of Targeting, Measurement and Analysis for Marketing,19(2), 69-84 [in text citation: M. Naseri and G. Elliott, 2011].

[53] Mondak, Jeffery J., and Karen D. Halperin ( 2008), A framework for the study of personality and political behavior, British Journal of Political Science, 38, 335362 [in text citation: Mondak and Halperin, 2008]

[54] McCrae, R.R and Costa Jr., P.T (1999), A five factor theory of Personality. In L. A. Pervin \& O.P. John (Eds), Handbook of Personality. Theory and Research (2ed), 139-153 [in text citation: McCrae and Costa, 1999].

[55] Mendonca (2016), Relating Big Five Factor Model to the acceptance and use of On-line Shopping, International Journal of Marketing Studies,8(3), 89-98 [in text citation: Mendonca, 2016].

[56] Moore, David J., William D. Haris and Hong C. Chen (1995), Affect Intensity: An individual difference response to advertising appeals, Journal of Consumer Research, 22, 154-164 [in text citation: Moore, Harris, and Chen, 1995].

[57] Mowen, John C. and M. Minor (1998), Consumer Behaviour, Upper Saddle River, NJ: Prentice Hall [in text citation: Mowen and Minor, 1998].

[58] Mondak, Jeffery J. (2010). Personality and the foundations of political behavior, Cambridge: Cambridge University Press [in text citation: Mondak et al, 2010].

[59] McCrae R.R., Paul Costa (2008), Empirical and theoretical status of the five factor model of personality traits, the Sage Handbook of personality theory and assessment,1, Personality Theories and Models, 273294 [in text citation: McCrae and Costa, 2008].

[60] Nair , A.A (2017), India growing fastest in ecommerce, says study. Your story. Retrieved from https:// yourstory.com/2017/02/e-commerce-forresterresearch [in text citation: Nair, 2017].

[61] Neveen F. Awad and Arik Ragowsky (2008), Establishing Trust in Electronic Commerce through Online Word of Mouth: An Examination across Genders, Journal of Management Information Systems, 24 (4), 101-121 [in text citation: Neveen F. Awad et al, 2008].

[62] Oskarsson, Sven, Christopher Dawes, Magnus Johannesson, and Patrik K. E. Magnusson (2012), The genetic origins of the relationship between psychological traits and social trust, Twin Research and Human Genetics, 15, 21-33 [in text citation: Oskarsson et al, 2012].

[63] Pavlou, P.A (2003), Consumer acceptance of electronic commerce: Integrating trust and risk with the technology acceptance model, International Journal of Electronic Commerce, 7 (3), 101-134 [in text citation: Pavlou, 2003].

[64] Sultan, F., Farley, J.U. and Lehmann, D.R. (1990), A meta-analysis of applications of diffusion models, Journal of Marketing Research, 27, 70-77 [in text citation: Sultan et al, 1990].

[65] Sarv Devaraj, Robert F. Easley and J. Michael Crant (2008), How does personality matter? Relating the Five-Factor Model to technology Acceptance and Use, Information Systems Research, 19(1), 93-105 [in text citation: Sarv Devaraj et al, 2008].

[66] Swickert, R. J., Rosentreter, C. J., Hittner, J. B., and Mushrush, J. E. (2002), Extraversion, social support processes, and stress, Personality and Individual Differences, 32, 877-891 [in text citation: Swickert et al, 2002].

[67] Schubert, P. (2000), The participatory electronic product catalog: Supporting customer collaboration in e-commerce applications, Electronic Markets, 10(4), 229-236 [in text citation: Schubert, 2000].

[68] Stolle, Dietlind (2002), Trusting strangers: The concept of generalized trust in perspective, Österreichische Zeitschrift für Politikwissenschaft, 31, 397-412 [in text citation: Stolle , 2002].

[69] Tyler, Tom R. (2001), Why Do People Rely upon Others: Social Identity and the Social Aspects of Trust, in: Karen Cook (Ed.), Trust in Society, Thousand Oaks, 285-306 [in text citation: Tyler, 2001].

[70] Todd A. Mooradian, Kurt Matzler and Lisa Szykman (2008), Empathetic responses to advertising: Testing a network of antecedents and consequences, Marketing Letters, 19( 2), 79-92 [in text citation: Todd A. Mooradian et al, 2008].

[71] Tuten, T., and Bosnjak, M. (2001), Understanding Differences in Web Usage: The Role of Need for Cognition and the Five Factor Model of Personality, Social Behavior and Personality , 29(4), 391-398 [in text citation: Tuten, Bosnjak, 2001].

[72] Tauber, E. M. (1972), Why do people shop?, Journal of Marketing, 36( 4), 46-49 [in text citation: Tauber, 1972].

[73] Vestre, Norris D. (1984), Irrational beliefs and selfreported depressed mood, Journal of abnormal psychology, 93, 239-241 [in text citation: Vestre, 1984].

[74] Vivek Singh Tomar, Ashok Sharma, Neerak Pandey (2018), Perceived benefits of Online Shopping: scale modification and validation, Indian journal of marketing, 48(12), 7-20 [in text citation: Vivek S. Tomar et al , 2018]

[75] Xianghua Lu, Sulin Ba, Lihua Huang and Yue Feng (2013), Promotional Marketing or Word-of-Mouth? Evidence from Online Restaurant Reviews, Information Systems Research, 24(3), 596-612 [in text citation : Xianghua $\mathrm{Lu}$ et al, 2013] 